\title{
A patient with Turcot Syndrome presenting with carcinoma of the rectum and a history of brain tumour
}

\author{
Wickramasinghe D.P, MBBS $^{1}$, Samarasekera D.N, MBBS, MS, FRCS(Ed.\&Eng.) ${ }^{2}$ \\ 1 Research Assistant, University Surgical Unit, The National Hospital of Sri Lanka. \\ 2 Professor of Surgery, University Surgical Unit, The National Hospital of Sri Lanka.
}

Key words: Turcot syndrome; Capsule endoscopy.

\section{Background}

Turcot syndrome (TS) is a part of the polyposis coli spectrum where there are multiple polyps in the large intestine associated with central nervous system (CNS) tumours. Though the eponymous name was coined after the paper by Turcot [1], many believe the first report was published 10 years ahead of him, in 1949 [2]. We report a case of a teenage boy affected with TS, whose mother also succumbed to rectal cancer.

\section{Case report}

A 19 year old boy presented to our unit with hematochezia of 2 months duration and subacute intestinal obstruction. He gave a history of episodic haematochezia throughout his childhood. Five years before admission, he had been diagnosed as having colonic polyposis following a barium enema, but defaulted follow-up.

Flexible sigmoidoscopy showed multiple colonic polyps from the anorectal junction and stenosis and ulceration of the upper rectum. Histology of the ulcerated area confirmed adenocarcinoma. A contrast CT scan of the abdomen demonstrated a large recto-sigmoid mass with perirectal fat infiltration and

Correspondnce: D.N. Samarasekera, University Surgical Unit, The

National Hospital of Sri Lanka.

Email: samarasekera58@yahoo.co.uk

The Sri Lanka Journal of Surgery 2010; 28(2):19-21. para-rectal and mesenteric lymphadenopathy. Capsule Endoscopy (CE) performed using the Pillcam Capsule (Givenimaging, Georgia, USA) demonstrated multiple small bowel and large bowel polyps.

The image (Figure 1) shows a large polyp with mucosal changes and several other small polyps in the large bowel, and to the knowledge of the authors, these are the first capsule endoscopy images of a patient with Turcot syndrome.

At the age of 10 years, he was diagnosed to have a medulloblastoma of the right cerebellar hemisphere and the vermis, and underwent

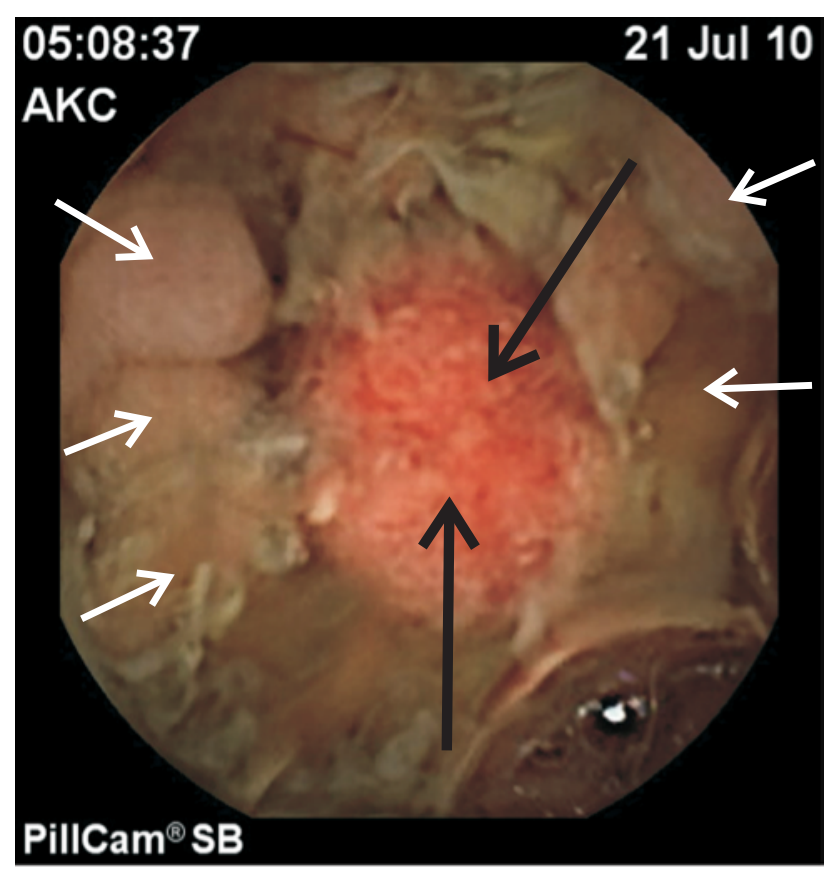

Figure 1. Capsule endoscopy image of the colon: Large polyp with mucosal changes (black arrows). Small polyps (white arrows). 
partial resection followed by chemo and radiotherapy. The resection severely affected his balance and hand writing resulting in him dropping out of school.

His mother had died of carcinoma of the rectum at the age of 51 years. His father declined screening but a sister had evidence of gastric and colonicpolyposis and underwent a successfulrestorative proctocolectomy procedure.

On examination, he was pale and had signs of cerebellar dysfunction but lacked café-au-lait spots, freckling or any other cutaneous and soft tissue manifestations.

\section{Conclusions}

The association of colorectal polyps with CNS malignancy and a possible genetic aetiology was first described by Turcot in 1959 [1]. Even though Crail reported a similar case 10 years before [2], he failed to make the causative association. TS is defined as a concurrence of colonic polyposis with a neuroepithelial brain tumour $[3,4]$. The commonest CNS malignancy associated with TS is glioblastoma.(Table 1)

TS is different to FAP in many ways $[4,5]$,

a) Patients usually present with symptoms in the second or early part of the third decade.

b) The number of polyps are less (20-100).

c) Large polyps over $3 \mathrm{~cm}$ are usually seen.

d)Malignant transformation occurs in the second or third decade of life.

Therefore, we suggest that doctors who see children with medulloblastoma should educate parents of the possibility of a larger underlying problem (i.e. colonic polyps) and screen patientswith medulloblastoma and their siblings for intestinal polyposis.

\section{References}

1. Turcot J, Despres JP, St Pierre F. Malignant tumors of the central nervous system associated with familial polyposis of the colon: report of two cases. Dis Colon Rectum. 1959; 2:465-8.
2. Crail H. Multiple primary malignancies arising in therectum, brain, and thyroid. . US NavalMed Bull 1949; 49:123-8.

3. Schneider T, Victor S. The Turcot syndrome (glioma polyposis) and its neurosurgical significance. Case report. Neurosurg Rev. 1993; 16:327-30.

4. Schroder S, Moehrs D, von Weltzien J, Winkler R, Otto HF. The Turcot syndrome. Report of an additional case and review of the literature. Dis Colon Rectum. 1983; 26:533-8.

5. Itoh $\mathrm{H}$, Ohsato $\mathrm{K}$. Turcot syndrome and its characteristic colonic manifestations. Dis Colon Rectum. 1985; 28:399-402.

6. Lewis JH, Ginsberg AL, Toomey KE.Turcot's syndrome evidence for autosomal dominant inheritance. Cancer. 1983; 51:524-8.

Table 1. Characteristics of the types of Turcot's syndrome

\begin{tabular}{|c|c|c|}
\hline & $\begin{array}{l}\text { Type I } \\
\text { (True Turcot's) }\end{array}$ & $\begin{array}{l}\text { Type II } \\
\text { (FAP variant) }\end{array}$ \\
\hline Lewis [6] types & 1,3 & 2 \\
\hline Itoh [5] types & 1,2 & 3 \\
\hline $\begin{array}{l}\text { Prevalent CNS } \\
\text { tumour }\end{array}$ & $\begin{array}{l}\text { Astrocytoma, } \\
\text { Glioblastoma }\end{array}$ & Medulloblastoma \\
\hline $\begin{array}{l}\text { Age at } \\
\text { presentation of } \\
\text { brain tumours }\end{array}$ & $<20$ years & Variable \\
\hline $\begin{array}{l}\text { Colonic polyps } \\
\text { size / number }\end{array}$ & $\begin{array}{l}\text { Large, }>3 \mathrm{~cm} / \\
\text { Low, }<100\end{array}$ & $\begin{array}{l}\text { Small / } \\
100-1000\end{array}$ \\
\hline $\begin{array}{l}\text { Colorectal } \\
\text { cancer } \\
\text { development }\end{array}$ & $56 \%$ & $21 \%$ \\
\hline Skin lesions & $\begin{array}{l}\text { Seen in } 53 \% \text {, } \\
\text { Café-au-lait } \\
(38 \%)\end{array}$ & $21 \%$ \\
\hline Family history & $\begin{array}{l}\text { Affected } \\
\text { siblings }\end{array}$ & $\begin{array}{l}\text { FAP, Affected } \\
\text { parents }\end{array}$ \\
\hline Inheritance & $\begin{array}{l}\text { Autosomal } \\
\text { recessive/ } \\
\text { ? Multifactorial }\end{array}$ & $\begin{array}{l}\text { Autosomal } \\
\text { dominant }\end{array}$ \\
\hline Genetic defect & $\begin{array}{l}\text { Mismatch repair } \\
\text { gene }\end{array}$ & $\begin{array}{l}\text { APC germ line } \\
\text { mutation at } 5 q 21\end{array}$ \\
\hline
\end{tabular}


Key Learning Points

Turcot's syndrome is transmitted by an autosomal recessive gene.

Familial adenomatous polyposis (FAP) arises from autosomal dominant inheritance.

In Turcot's syndrome, bowel cancer arises in the second and third decades of life. In FAP, bowel cancer is common in the fourth decade and beyond.

Bowel cancer screening in Turcot's syndrome is recommended only for siblings. 